\title{
Studies on Photoelectric Performance of Natural Dyes from Safflower
}

\author{
Su-Qing Zhao ${ }^{1}$, Yu-Long Xie 2,*, Zheng-Xing $Q i^{2}$, Peng-Cheng Lin $^{3}$ \\ ${ }^{1}$ School of Physics and Electronic Information Engineering, Qinghai Nationalities University, Xining, \\ Qinghai, 810007, China \\ ${ }^{2}$ School of Chemistry and Chemical Engineering, Qinghai Nationalities University, Xining, Qinghai, \\ 810007, China \\ 3 College of Pharmacy, Xining, Qinghai, Key Laboratory of Plant Resources of Qinghai-Tibet \\ Plateau in Chemical Research, 810007, China \\ *E-mail: yulongxie2012@126.com
}

doi: $10.20964 / 2018.02 .38$

Received: 1 October 2017 / Accepted: 10 December 2017 / Published: 28 December 2017

The $\mathrm{TiO}_{2}$ nanoparticles thin films was used to prepare the dye-sensitized solar cells (DSSCs) as photoelectrode and natural dyes as photosensitizers. The sensitized $\mathrm{TiO}_{2}$ based solar cell used nature dye carthain and hydroxysafflor yellow A as sensitizer, which were extracted from the abundant Hehuang safflowers in Qinghai province of China. The DSSCs exhibited short-circuit photocurrent density $\left(J_{\mathrm{sc}}\right)$ value of $2.193 \mathrm{~mA} \cdot \mathrm{cm}^{-2}$, open-circuit photovoltage $\left(V_{\mathrm{oc}}\right)$ of $0.61 \mathrm{~V}$, the fill factor $(\mathrm{FF})$ of 0.50 and solar energy-to-electricity conversion yield $(\eta)$ of $0.664 \%$. Natural dyes as sensitizers for DSSCs are promising because of their environmental friendliness, low-cost and designable polychrome modules.

Keywords: Natural dye, Dye-sensitized solar cells, Safflower

\section{FULL TEXT}

(C) 2018 The Authors. Published by ESG (www.electrochemsci.org). This article is an open access article distributed under the terms and conditions of the Creative Commons Attribution license (http://creativecommons.org/licenses/by/4.0/). 